\title{
Overview of Wound Healing Siddha Medicines
}

\author{
Vajiravelu Sivamurugan*1, Murugan Anbarasu ${ }^{1}$, Ponmudi Priya ${ }^{2}$, Gopal Jeya ${ }^{1}$, Ravikumar Dhanalakshmi ${ }^{1}$ and \\ Viswanathan Vinitha ${ }^{1}$ \\ ${ }^{1} P G$ and Research Department of Chemistry, Pachaiyappa's College, India \\ ${ }^{2} P G$ and Research Department of Zoology, Pachaiyappa's College, India \\ *Corresponding author: Dr. V Sivamurugan, Assistant professor, Department of Chemistry, Pachaiyappa's College, Chennai-600030, \\ India
}

\begin{abstract}
The present article is intended to deliver a bird's eye view of traditional Siddha medicines prescribed for the wound healing process for various types ulcers, wounds and few skin diseases including eczema, scabies, psoriasis etc. The article may not be exhaustive, however, we have attempted give an overall impression on the Siddha medicines, especially for the readers, those are not familiar with Indian traditional system of medicines. We have listed the medicinal plants (botanical name and Tamil name) and their medicinal uses. Finally, the mode of Siddha drug formulation based on the diseases also summarised in order to understand the Siddha formulations.
\end{abstract}

Keywords: Herbal formulation; Indian traditional medicinal system; Medicinal plants; Siddha; Wound healing

\section{Introduction}

The siddha medicines are originated from the envisions and constant experimentation of sages (Siddhar in Tamil, an ancient Indian language) on medicinal plants, minerals, animals, who were wished to defeat death and live longer using medicinal herbs and their formulations, which subsequently evolved as one of the Indian Traditional System of medicines, i.e., Siddha medicines [1]. According the ancient Siddha Tamil literature, there are 18 siddhas, who are majorly contributed to the development of the Siddha medicines for various kinds of diseases including wound healing and skin diseases. Among them, the sage Agastyar being the first siddhar in the siddha lineage, who contributed to large portion of Siddha literature. The Siddha system of medicines have been developed for both internal and external applications. The drug has been formulated into various types viz., capsules, tablets, powder, decoctions and oil form in order to facilitate the intake of medicine without hustles for the patients' convenience. In order to protect the rights of ancient traditional system of medicines, the Government of India has taken necessary steps to protect the traditional medicinal systems such as Ayurveda, Unani, Yoga and Siddha in the form of digital library and almost 223,000 formulations have been digitised in this library with the proper citations of literature to the drugs [2]. The Siddha medicines as spread as 32 types of internal medicine and 32 types of external treatment viz., non invasive surgery, bloodletting, leech therapy etc. The Siddha system is found to very effective in healing skin problems such as psoriasis, eczema, leucoderma, vitiligo, scabies etc. with variety of drugs and their formulations [3]. Geographically, the siddha medicines has widely spread in south east Asian countries such as Sri Lanka, Burma (Myanmar), Cambodia, Malaysia and Indonesia. This medicinal system has a long history and founded in Ancient Tamil Literature and Tamil culture of South India, which is contemporary to Ayurvedic medicinal system originated from North India at the same evolution period [4].

\section{Siddha Medicines for Skin Diseases and Wound Healing}

Though, the Siddha medicines having capability of treating various kinds of ailments, we have selected the medicines that specifically prescribed for the treatment of wounds and skin diseases including chronic and non-chronic types. The ulcers or wounds, which are developed by various physiological disorders also by diseases put the patients' life in pathetic conditions and in some cases it could become life threatening. For example, the untreated diabetic foot ulcers, leprosy wounds, venous and arterial 
ulcers and pressure ulcers may developed as chronic wounds and continuous treatment is necessary for the healing. Similarly, the skin diseases such as eczema, psoriasis, scabies, itching, vitiligo pruritus and carbuncles also critical to human life. The following (Table 1) summarises the use of various medicinal plants used for treatment for wound healing and treatment for skin diseases. The drug may be obtained using parts or whole plants as a single drug or combinations with other drugs/minerals in the form of various formulations according to the severity of the disease. For the convenience of readers, we have mentioned the botanical name of the plant and its Tamil name used in Siddha and respective diseases are listed in Table 1 . In addition, the disease and their equivalent Tamil name in Siddha formulatory and Siddha pharmacopeia is also listed in the (Table 1) $[5,6]$. The juice or extract or decoction of above medicinal plants obtained from leaf, bark, flower, root or whole plant used for formulating the medicines prescribed in The Siddha Formulatory of India by using various formulations [5].

Table 1: The medicinal plants used in Siddha medicines for the treatment of skin diseases, ulcers and wounds (Equivalent Tamil language given in brackets) $[5,6]$.

\begin{tabular}{|c|c|c|c|}
\hline S. No. & Botanical Name & Traditional Name & Treatment \\
\hline 1 & Glycyrrhiza glabra L. & Athimathuram (Stolon and Root) & Peptic ulcer, herpes, eczema and psoriasis \\
\hline 2 & Aconitum heterophyllum Wall. ex. Royle & Athiviúayam (Root) & All kinds of wounds \\
\hline 3 & Indigofera tinctoria L. & Avuri (Whole Plant including root) & Acid peptic ulcer (Kunmam) \\
\hline 4 & Nardostachys grandiflora DC. Syn. & Cadamancil (Rhizome) & $\begin{array}{l}\text { General term used for the group of various Skin } \\
\text { diseases (Kuttam) }\end{array}$ \\
\hline 5 & Tinospora cordifolia (Willd.) Miers. & Cìnthil thaûúu (Stem) & $\begin{array}{l}\text { Skin diseases, Scabies/Skin ulcers (Ciranku) and } \\
\text { Pruritus(Cori) }\end{array}$ \\
\hline 6 & Cuminum cyminum L. & Cìrakam (Fruit) & Acid Peptic Disease \\
\hline 7 & Psoralea corylifolia L. & Kërpõkarici (Fruit) & $\begin{array}{c}\text { Eczema (Karappan), leukoderma } \\
\text { (Venkuttam),Vitiligo (Venpulli), leprosy (Kuttam) } \\
\text { and psoriasis }\end{array}$ \\
\hline 8 & Nigella sativa L. & Karuncìrakam (Seed) & Psoriasis, ulcers (Pun) and peptic ulcers \\
\hline 9 & Picrorhiza kurroa Royle ex Benth. & Kadukurõkini (Rhizome and Root) & Eczema, ulcers and vitiligo \\
\hline 10 & Vernonia anthelmintica (L.) Willd. & Kattu cìrakam (Fruit) & Acid peptic ulcer \\
\hline 11 & Curcuma longa L. Syn. C. domestica Valeton & Mancal (Rhizome) & Ulcers \\
\hline 12 & Terminalia arjuna (Roxb.) W. \& A. & Marutham pattai (Stem bark) & Ulcers \\
\hline 13 & Crateva magna (Lour.) DC. & Mavilinkappattai (Stem bark) & Chronic ulcers \\
\hline 14 & Hemidesmus indicus (L.) R. Br. & Nayuruvi camulam (Whole Plant) & Acid peptic ulcer \\
\hline 15 & Smilax china L. & Paranki cakkai (Tuberous root) & Eczema, ulcers and carbuncle (Pilavai) \\
\hline 16 & Stereospermum chelonoides (L.f.) DC. & Pathiri ver (Root) & Eczema and ulcers \\
\hline 17 & Alpinia galanga Willd. & Perarattai (Rhizome) & Scalp ulcer (Talaippun) \\
\hline 18 & Pongamia pinnata L. & $\begin{array}{l}\text { Punkam verpttai (Root bark) Punkam } \\
\text { viththu (Seed) }\end{array}$ & Ulcers and eczeme \\
\hline 19 & Terminalia belerica (Gaertn.) Roxb. & Tanrikkay (Fruit) & Penile sore (Ankurippun) \\
\hline 20 & Piper longum L. & Thippili (Fruit) & Acid peptic ulcer \\
\hline 21 & Piper cubeba L. f. & Valmilaku (Fruit) & Acid peptic ulcer \\
\hline 22 & Celastrus paniculatus Willd. & Valuzuvai (Seed) & Ulcers \\
\hline 23 & Azadirachta indica A. Juss. & Veppampazam (Fruit) & Skin diseases \\
\hline 24 & Crotalaria juncea Linn. Papilionaceae & Sanal (Seeds) & Psoriasis and impetigo \\
\hline 25 & Hydnocarpus kurzii (King)Warb & Niradi-muttu & Psoriasis, eczema and dermatitis \\
\hline 26 & Indigofera aspalathoides Vahl ex DC & Sivanaarvembu & psoriasis and erysipelas \\
\hline 27 & Leucas aspera Spreng & Thumbai (Leaves) & $\begin{array}{l}\text { Juice is used as an external application for psoriasis, } \\
\text { chronic skin eruptions and painful swellings }\end{array}$ \\
\hline 28 & Semecarpus anacardium Linn. f. & Shenkottei (Kernel oil) & Antiseptic, gout, leucoderma, psoriasis and leprosy \\
\hline 29 & Thespesia populnea Soland. ex Correa. & Poovarsu (Root, fruit and leaf) & Psoriasis, scabies and other cutaneous diseases \\
\hline 30 & Vernonia cinerea Less & Naichotte Poonde (Seeds) & Leucoderma, psoriasis and other skin diseases. \\
\hline 31 & Apium graveolens Linn & Celery-keerai (Seeds) & Chronic skin disease and psoriasis \\
\hline 32 & Canarium strictum Roxb & Karunkungiliyam (Resin) & Psoriasis and pityriasis \\
\hline 33 & Carica papaya Linn & Pappali (latex of unripe fruit) & $\begin{array}{l}\text { Eczema, psoriasis, sloughing wounds, carbuncles } \\
\text { and eschar of burns }\end{array}$ \\
\hline
\end{tabular}




\begin{tabular}{|c|c|c|c|}
\hline 34 & Alkanna tinctoria (L.) Tausch & Ratthapaalai & Indolent ulcers, wounds \\
\hline 35 & Aquilaria agallocha Roxb & Akil kattai & Used as a liniment in skin diseases \\
\hline 36 & Bauhinia tomentosa Linn & Kokkumandarai & Seed-used for wound Healing \\
\hline 37 & Bridelia retusa (Linn.) Spreng & Mulluvengai & Paste of the stem bark is applied to wounds \\
\hline 38 & Buchanania lanzan Spreng & Mudaima & Powdered or crushed leaves are applied to wounds \\
\hline 39 & Calendula officinalis Linn & Thulvkka Saamanthi & on poorly healing wounds \\
\hline 40 & $\begin{array}{l}\text { Carissa carandas Linn. var. congesta (Wt.) } \\
\text { Bedd. }\end{array}$ & Kalakke & $\begin{array}{l}\text { Juice of the fresh plant is used for infected wounds } \\
\text { that refuse to heal. Root-paste used for diabetic } \\
\text { ulcer Wounds and sores with pain and swelling }\end{array}$ \\
\hline 41 & Carthamus tinctorius Linn. & Chendurakam & Wounds and sores with pain and swelling \\
\hline 42 & Centella asiatica (Linn.) Urban. & Vallaarai & $\begin{array}{l}\text { Chronic postsurgical and post trauma wounds; treat } \\
\text { second and third degree burns }\end{array}$ \\
\hline 43 & Chloroxylon swietenia DC. & Karumboraju & Anti-inflammatory and antiseptic \\
\hline 44 & Coscinium fenestratum Colebr. & Maramanjal & $\begin{array}{l}\text { For dressing wounds and ulcers, and in cutaneous } \\
\text { leishmaniasis }\end{array}$ \\
\hline 45 & Dendrophthoe falcata (Linn. f.) Etting & Pulluri & Wounds \\
\hline 46 & Datura metel Linn & Oomatthai & Seed, leaf and root used for antidermatosis \\
\hline 47 & Wrightia tinctoria R. Br. & Irum-paalai & Used for piles and skin diseases \\
\hline 48 & Rubia cordifolia Linn & Manjitti & Piles, ulcer and skin diseases \\
\hline 49 & Acalypha indica Linn. & Kuppaimeni & Leaf juice used for scabies \\
\hline 50 & Ficus carica Linn & Semaiatti & $\begin{array}{l}\text { Leaf extract used in lucoderma Bark juice used for } \\
\text { eczema and other skin diseases }\end{array}$ \\
\hline
\end{tabular}

\section{Mode of Vehicle (The Drug Formulation System)}

The siddha medicinal formulation system have variety of mode of drug delivery system. Mostly, it is classified based on the type and severity of the disease. Some disease needed internal medicine and some may needed external applications. So, the Siddha system is consists of various formulations viz., powder, lotion, capsule, oil form etc. Since, we are highlighting about the wounds and skin diseases, the mode of delivery for various diseases are summarised in (Table 2). According to the Siddha formulatory of India, each Siddha formulation have well defined preparation procedure [4]. It has to be strictly followed for the preparation, and colour, character tests, shelf life and storage method for the each formulation is clearly discussed in the Siddha formulator of India. The summary of above mentioned formulations have been discussed here,

Table 2.

\begin{tabular}{|c|c|}
\hline Disease & Mode of delivery (Siddha formulation) \\
\hline Eczema (Karappan) & $\begin{array}{l}\text { Kullikai, tailam, centuram, meluku and } \\
\text { ilakam }\end{array}$ \\
\hline Leprosy (Kuttam) & Ney, churnam \\
\hline $\begin{array}{l}\text { Acid peptic ulcer } \\
\text { (Kunmam) }\end{array}$ & $\begin{array}{l}\text { Kuzhambu, curnam, patankam, kulikai, } \\
\text { tailam, ilakam, centuram, ennai, meluku and } \\
\text { parpam }\end{array}$ \\
\hline Scabies (Ciranku) & $\begin{array}{l}\text { Meluku, ennai, ney, patankam, parpam and } \\
\text { tailam }\end{array}$ \\
\hline Pruritus (Cori) & $\begin{array}{l}\text { Parpam, tailam, meluku, ennai, ney and } \\
\text { ilakam }\end{array}$ \\
\hline Carbuncles (Pilavai) & Meluku \\
\hline Psoriasis (Tol noy) & Parpam, ney and tailam \\
\hline
\end{tabular}

a) Curnam: It is a finely powdered form of a drug/drugs and free from foreign matter. b) Centuram: Medicines made from grinding of plant juices or extracts with metal minerals followed by calcination or burning or sublimation.

c) Ilakam: It is a sweetened semisolid medicinal preparation with the addition of juices of medicinal plant and sugar and heated till a thick syrup is obtained.

d) Kuzhambu: It is a semi liquid form of medicines. Simple mixtures of juices of medicinal plants with sugar or other drug powder and heated to the consistency of thick syrup.

e) Meluku: This kind of medicine prepared by way of grinding well the drug or by heating the drugs until a waxy kind of substance obtained.

f) Ney: It is kind of medicine that obtained by boiling the drugs with ghee.

g) Parpam: The powder form of substances obtained after the calcination process.

h) Patankam: It is prepared by sublimation of organic or inorganic drugs.

i) Tailam: It is a kind of medicated oil preparation done by boiling the decoction, milk and paste of drugs with oils for a stipulated period of time.

\section{Conclusion}

The use of Siddha drugs for the treatment of various types of skin diseases and wounds has a very long history. It could be clearly witnessed from the ancient Siddha Tamil literature. The drugs are available in various formulations and chosen according the type of disease and facilitate the intake of medicine. The formulations of 
siddha drugs which includes both internal and external applications depending on the severity. For the detailed preparation of Siddha drugs, the Siddha formulatory of India must be referred. The Siddha has treatment for various other kinds of diseases as well and it has lot to offer to the society.

\section{References}

1. ht tp s: / / w w w. nis c hennai.org/sidd hamedicine htmlAbout?pgname=siddhamedicine
2. http://www.tkdl.res.in/tkdl/langdefault/common/Home.asp?GL=Eng

3. https://nischennai.org/uploaded/pdf/e-Book-NIS.pdf

4. (1992) The Siddha formulatory of India, Part 1, (1 $1^{\text {st }}$ edn), Published by Government of India, Ministry of Health and Family Welfare, Department of Health.

5. (2008) The Siddha Pharmacopoeia of India, Part I, (1 $1^{\text {st }}$ edn), Government of India, Ministry of Health and Family welfare, Department of Ayurveda, Yoga \& Naturopathy, Unani, Siddha, and Homoeopathy (AYUSH), India.

6. Khare CP (2007) Indian Medicinal Plants. An Illustrated Dictionary. Springer Science+Business Media, LLC.

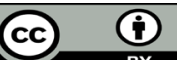

This work is licensed under Creative Commons Attribution 4.0 License

To Submit Your Article Click Here:

Submit Article

DOI: 10.32474/OAJCAM.2019.01.000124

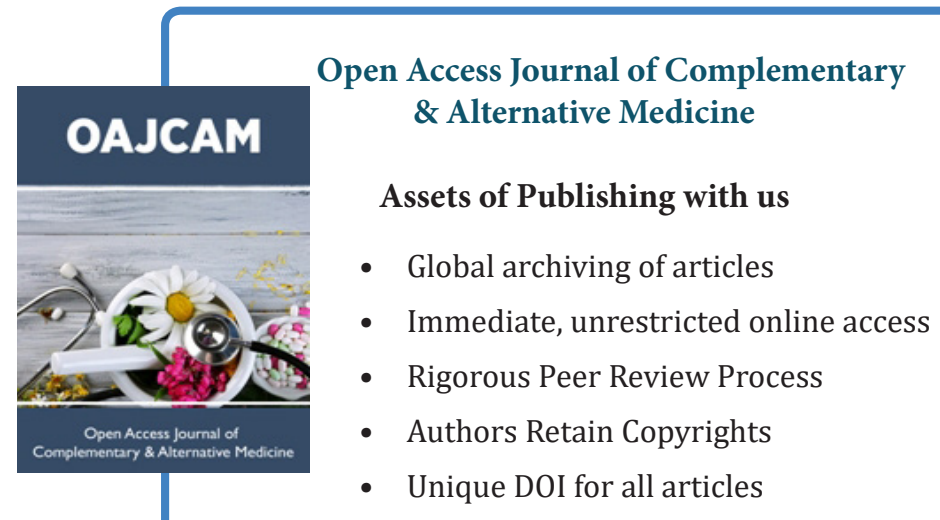

